\title{
Nemzetiségi térképek mint a hatalmi beszédmód formái (II. rész)
}

\section{Ethnic maps as forms of the authoritarian mode of speech (part II)}

\author{
KEMÉNYFI RÓBERT
}

KULCSSZAVAK: térbeli fordulat, nyelvhatárakció, etnikai térképek, emléknyomok, hatalmi beszédmód, nemzetiségi politika

ABSZTRAKT: A magyar kartográfiatörténet-írás nagy hagyományokkal és rendkivül gazdag eredményekkel rendelkezik. Azonban a társadalomtudományokban végbement "térbeli fordulat" eredményeként a kartográfia tudománya is felismerte: ahhoz, hogy árnyalt képe legyen - jelen esetben - a nemzeti térképírási módokról, mindenképpen figyelembe kell vennie azł a társadalmi és kulturális hálót, amelyben az adott térképek születtek. A múlt század utolsó évtizedeiben lezajlott úgynevezett memory-boom az emlékezeti hely fogalmába beemelte a nem konkrét fizikai helyekhez köthető nemzeti emlékezeti narrativákat is. A "hely" az új megközelítésben inkább széles értelemben vett mentális közeget jelent, mintsem objektív teret. Olyan relatív kulturális színterekről van ebben a felfogásban szó, amelyek a nemzeti identitást fenntartó kollektív emlékezetet folyamatosan szervezik, áramlásban tartják és újra meg újra (akár újabb és újabb tartalommal) aktualizálják. Nemzeti ünnepek, archivumok, könyvtárak, szimbolikus aktusok, épületek, dalok, rítusok, akár etnikai térképek jelenítik meg a nemzet szellemét. A nemzeti emléktárak mélyén olyan dokumentumok találhatók, amelyek a politikai és az etnikai térképészet kapcsolatát kézzelfoghatóvá teszik, sőł a gyakorlati politika direkt befolyását a társadalomtudományok szabályainak megfelelően szigorúan bizonyítani is képesek. A tanulmány egy olyan nyelvhatárakció fennmaradt igen részletes dokumentációját értelmezi, amellyel a feledés homályából előhivhatók azok a közvetlen politikai szándékok, amelyek a térképtörténet-írásban csupán egy-egy mondattal jelzett - és ezért csendesen meghúzódó - tulajdonképpen közigazgatási térkép elkészítése mögött ismerhetők fel. Még érdekesebbé teszi ennek a forrásnak a feldolgozását az a tény, hogy a ránk maradt dokumentumok tulajdonképpen egy történeti mítoszt is megkérdőjeleznek. Nevezetesen azt, hogy a politika természetesen szólt bele a nemzetiségi kartográfiába az első világháború utáni évektől kezdődően (amely befolyás az ismert események miatt (Trianon - 1920) hallgatólagosan el is fogadható - mondja kollektív emlékezetünk). Azonban a bemutatandó, egyértelmúen politikai hátterú nyelvhatárakció majd két évtizeddel a trianoni döntés előtt zajlott le.

KEYWORDS: spatial turn of events, language-boundary action, ethnic maps, memory traces, authoritarian mode of speech, ethnic policy

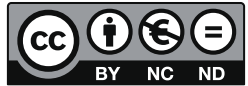


ABSTRACT: The history of Hungarian cartography boasts a long tradition and priceless achievements. The 'spatial turn of events' effected in social sciences, however, have resulted in an important recognition by the field of cartography. In order to gain a nuanced picture of the methods of national cartography (as it is attempted here), the social and cultural networks in which the maps in question were drawn, must definitely be taken into consideration. The so-called "memoryboom" which took place in the last decades of the previous century imported narratives of national memory, not linked to actual physical sites, into the domain of lieux de memoires. In this novel approach, "site" stands for mental milieu in a broad sense rather than objective space. This approach involves relative cultural scenes which constantly organize the collective memory underpinning national identity, ensure its unhindered flow and regularly update it (as the case may be, with ever newer content). The spirit of the nation is represented by national holidays, archives, libraries, symbolic acts, buildings, songs, and rites as so many ethnic maps. Buried deep in national troves of records, there are documents that offer tangible links between political and ethnic map-making. What is more, they can definitively prove the direct influence of practical politics according to the rules of social sciences. The study interprets the meticulously detailed documentation of a language-boundary action. This may unearth from obscurity the direct political intentions quietly lurking behind the poorly-publicized process of drawing a map for public-administration purposes. The analysis of this source is made even more intriguing by the fact that the surviving records effectively question the validity of a historical myth. Notably, the one that, as of the years immediately following World War I, it was natural for politics to interfere in ethnic cartography. (Considering some well-known events (Trianon - 1920), this influence may as well be acceptable - our collective memory says). However, the language-boundary action to be presented here - which had manifested itself against an obvious political backdrop - had come about nearly two decades before the Treaty of Trianon.

\section{A térképek mint kódolt üzenetek}

\section{Elvi keretek}

Ha Teleki szavaiból indulunk ki, hogy térségünkben nincsenek és nem is létezhetnek politikailag semleges térképek (Teleki 1937), akkor az etnikai kartográfia részét képzi az etnopolitika eszköztárának. Teleki állásfoglalását úgy is értelmezhetjük, hogy a nemzetiségi térképek alapvetően kiesnek a szigorú kartográfiai tudományosságból. Az Otto Neurath osztrák társadalomteoretikus által megteremtett kifejezés segítségével úgy fogalmaznék, hogy az etnikai kartográfia csupán (vagy írjuk így: inkább) képstatisztikai metódus. Olyan módszer, „amelyet akkor akarunk használni, ha elképzelésünk, ideológiánk bemutatására a képi megjelenítés sokkal többet ígér, mint a szavak" (Neurath 1991, 423.). Így válhattak az etnikai térképek az Európa középső felén élő népek nemzetállami törekvéseiben „grafikai ikonokká” (részletesebben l. lentebb), a nemzeti-területi egység jelképévé.

Úgy vélem, hogy a Közép-Európa nemzetei által szerkesztett etnikai térképsorok erősen szitációfüggők. Érthetjük ezt a hangsúlyozandó tartalomra is 
(például mit emel ki a térképen vizuálisan a szerkesztő), ám elsősorban itt most a „közegre” utalnék, amelyben a térképek készülnek. Éppen ezért külön elemzést érdemelne, hogy hol és hogyan használják e térképeket, s ezek milyen módon befolyásolják a társadalmi tevékenységet, illetve e földabroszokról milyen módon alakulnak a nemzeti közösségek képzetei, és fordítva, hogyan határozzák meg a társadalmi elvárások a térképek vizuális tartalmát (Miklós 1980, 44). Úgy látom, hogy az etnikai térképek a jelentésüket (értelmüket, információs tartalmukat) alapvetően társadalmi kontextusokban kapják meg (Schier 2003, 241). Gömöri kutatásaim alatt például kis felvidéki magyar falvak kulturális helyiségeiben, polgármesteri irodáiban találkoztam ma készült magyar etnikai térképekkel. (Általában persze csupán „sub rosa”, azaz feltekerve, szekrényben tartva, de mégis néha-néha elővéve...) A lokális példa mellett említsük meg a makroszintet is! Átfogó, egy-egy nagyobb térséget lefedő nemzetiségi térképnek napjainkban a szimbolikus politikai/etnikai konfliktusokban továbbra is szerep jut. Gondoljunk csak a térségünk országaiban lezajlott közigazgatási, választási körzetátalakítás etnikai-területi vonatkozásaira (Kocsis 1995)! Sokszor kifejezetten kormányzati vagy politikai kisebbségi szervezetek megrendelésére készítenek ma is térképeket. (Sőt! Az adott etnikai térkép elkészítéséhez pénzügyi támogatást nyújtó - általában kisebbségi politikai hátterü - szervezetek ma is meghatározzák a térkép főbb színpreferenciáit. Így például a magyarság állandósult, domináns piros tónusát [Kocsis Károly szíves szóbeli közlése]). A nemzetiségi kartográfia politikai döntéshozói háttere nem titok, hiszen az MTA Földrajztudományi Kutatóintézet weblapja direkt fel is sorolja a kormányzat és kisebbségi egyesületek, pártok által támogatott etnikai térképészeti munkálatokat. ${ }^{1}$ Ezektől a helyzetektől kapja meg tehát az adott térkép a többletjelentését. Nem igényel hosszas magyarázatot, hogy például a szocializmus időszakában hogyan léptek a nemzetiségi térképek jelentés nélküli holttérbe, veszítették el jelentőségüket, és vált az egész etnikai kartográfiai gyakorlat csupán a nemzet néma hagyományának (elnyomott) emlékezetrétegévé.

Nem lehet tehát a térképeket kiemelni abból a társadalmi/történeti közegból, amelyben születtek. Nem lehet a későbbi korok - a Zeitgeist - szűrőjén keresztül nézni az egykori kontextusok elhallgatásával, akár nem ismerésével a nemzetiségi térképeket. Ennek értelmében: ha a térképet egyfajta használatcentrikus szemiotikai modellnek tekintjük, akkor csak a funkcióját helyezhetjük a vizsgálat középpontjába. Azt lehet (esetleg) felderíteni, hogy mely feltételek mellett lehet bizonyos eredménnyel az egykor készült térkép akkori célját ma is értelmezni. Azaz szinte laboratóriumi zártsággal napjainkban azt vizsgálni, hogy milyen módon vehetett részt a térkép az adott kor kommunikációs hálójában. (A kérdést részletesen l. Horányi 2006, Novitz 2003.)

Viktor Klemperer már hatvan évvel ezelőtt, az azóta világhírűvé vált naplókötetében elemezte a hatalmi beszédmódok primitív metaforáit, a beszédmód stílusát, leegyszerüsítő tendenciáit (Klemperer 1984). Az elmúlt évtizedek nép- 
rajzi és antropológiai vizsgálatai árnyaltan elemezték a hatalmi kifejezésmódok működési hálóját. A könyvtárnyivá terebélyesedő kommunikációelméleti szakirodalom modelljei, alapképletei, fogalmai (feladó, csatorna, vevő, kódolás, dekódolás stb.) alkalmas kereteket nyújtanak a térképek üzenetfunkciójának elemzéséhez is (Anderson 2005, Rosengren 2006, Terestyéni 2006).

Ahhoz, hogy az eljuttatandó üzenetet a célközösség képes legyen befogadni, a hírnek és a közvetítőcsatornáknak több feltételt kell együttesen teljesíteniük. (A szempontrendszert esettanulmányon keresztül részletesen l. Biró 1993.) A nemzetiségi térképek hatalmiüzenet-szerepét maga a készítési jelkulcs, a megjelenítendő adatok és a fentebb már említett, a térképekkel történő találkozási helyzetek alapvetően igazolják (például fali "díszítőfunkció” egy kormányzati irodában), ugyanis térségünk országainak kartográfiai gyakorlata arra törekszik, hogy az oktatásban, kutatásban, médiában kialakuljon a következő hét dolog.

(1.) A befogadók körében a térkép (az üzenet) olvasata (az, hogy elsődleges, saját nemzeti érdeket fejez ki) váljon közössé! A megjelenités módja: A térképeket vizuálisan súlypontozzák, például beállítják a „nemzeti” centrum - kisebbségi periféria viszonyt. Az „etnikai tereket”, történeti régiókat vizuálisan széttördelik, a saját népcsoportot kedvezően megjelenítő színkódot alkalmaznak.

(2.) Ezeknek a térképeknek a tartalmáról a kisközösségi hálózatokban körvonalazódjék egyetértés, és az utólagos beszélgetés során az üzenet váljon személyessé. Megjelenités (pontosabban a térképi ábrázolás értelmezése): A nemzetiségi statisztikai adatok felvitele nyomán a térképen látható etnikai téralakzatokat, rajzolatokat minősítik, a helyes értelmezésüket közvetítik. Például azt, hogy a saját szórványterületek „etnikai bástyák”, ,etnikai túszhelyzetben lévő nemzettestek". A kirajzolódó etnikai határ mentén fekvő községek "etnikai frontharcosok". Azaz a kultúra tényleges lokális mintázatától, az etnicitás mindennapi termelődésétől eltávolít a generalizált „etnikainak”, „nemzetinek" nevezett adatok egyszerü térképi megjelenítése. Ennek a képteremto folyamatnak az eredményeként, tehát az így szerkesztett vizuális értelmezési mezőben a kirajzolódó térképzet „teremtett lénnyé” (Biró 1993) válik. Ez azt jelenti, hogy az etnikai térkép önálló hatást kiváltó eszközként etnopolitikai döntések, tervek számára biztosít állandó interpretációs hátteret, hivatkozási felületet.

(3.) Az üzenetet azonosítsák az elfogadandóval, azaz a média, a tudományos csatornák, a publikációk ne csupán hordozói, hanem a hatalom megjelenési módjaivá váljanak. Megjelenités (pontosabban a térképi értelmezése): Az etnikai térképeket nemzeti szinten egységesen dekódolják. Szöveges elemzésekben a körvonalazódott etnikai térrajzolat alapján itt-ott veszélyeztetett magyar tömbterületekről, szórványokról beszélnek.

(4.) Az üzenetet periodikusan ismételgessék és

(5.) aktualizálják. Megjelenités: Az egymást követő népszámlálások adatait újra és újra azonos módszertant (ábrázolási módot, színkódot) alkalmazva térképre viszik, az előző rajzolatokkal összevetik. 
(6.) Az üzenet formai jegyei legyenek ritualizáltak. Megjelenítés: Például a színkód jellege és a térkép méretaránya legyen méltó, a rajz legyen részletes és lenyügöző (,lepedőnyi” papírokon „nagy” etnikai terek).

(7.) Az üzenet érvényességét ki kell terjeszteni. Megjelenités (pontosabban a térképi értelmezése): A vizuálisan megjelenő veszteségolvasatok nemzeti jellegét fel kell erősíteni, a kedvezőtlen utódállami kisebbségpolitikát fel kell nagyítani, az asszimiláció, a demográfiai összetétel negatív változásának tényleges szociális/életmódbeli okait el kell tompítani.

„A kartográfia (mai értelmében térképszerkesztés, -rajzolás folyamata), mint maga a megismerés is, szükségszerü leegyszerüsítés, amely lehetővé teszi számunkra, hogy lássuk, hol vagyunk és merre haladunk" (Huntington 1998). A térkép - természetéből következően - a kulturális jelrendszerek hálójába is pontosan beilleszthető, sőt a térkép a képmásszerü jelek típusának is egyik plasztikus példája. A jelelmélet szerint a térkép tehát ikon, képszerü jel, amely valamiképpen hasonlít a tárgyára. A térképi (képszerü) jel fontos tulajdonsága a jelrendszeren belül, hogy a vevő képes dekódolni az üzenetet nyelvektől függetlenül, hiszen ez a jeltípus vizuális módon, egyetemes eszközkészlettel kódolja a közvetítendő üzenetet (Hoppál 1992). A térkép univerzális kódoltságából azonban az is adódik, hogy szükségszerüen a valóság leegyszerüsítése, ezért tehát a térkép csupán eszmei modell absztrakció. A térképnek az ikonikus természete mellett szimbolikus vonásai is vannak. Hiszen egyrészt olyan jel, amely a jelölt tárgyra pusztán saját (megállapodott „térképi") jellemzőivel utal, másrészt a térkép értelmező híján elvesztené azt a jellegzetességét, amely őt jellé teszi. Különösen igaz ez az absztrakció a társadalmi jelenségek térképi vizualizációjára (például a népsűrűségre, jelen esetben a nemzetiségre), mert ezekben az esetekben - a domborzati térképektől eltérően - még csak hasonlóság sincs a térképi jel és a jelölt alakja között. Standardizált kódok helyettesítik a valódi reprezentációt (Gombrich 2003). A térkép tehát a megismerés sajátos eszköze, konkrét és szemléletes, egyes célokra jobban, más célokra kevésbé alkalmazható. A térképi egyszerüsítés (generalizálás) jellegét a térkép rendeltetése dönti el. A térkép szerkesztője határozza meg, hogy milyen adatokat milyen alaptérképre visz fel (Török 1987, Peirce 2004).

E kettős arculat - személy és funkció - viszonyrendszerében tekint a mai „kritikai geopolitika” (a geopolitika ideológiailag terhelt örökségéről l. Gombár 1983) retorikai szövegként is a térképre, hiszen a térkép egyrészt szerkesztője értékrendjét, álláspontját tükrözi, másrészt a térképnek nemcsak az alkotója, hanem a tőle független, esetleg általa meg sem célzott működése is meghatározza e „szöveg” olvasatát (Harley 1989). Vagyis a térképi közlemény szemiotikai státusát - jelen esetben tehát szövegként értelmezve - a térkép generálásában részt vevő kódok hozzák létre (Horányi 2006).

Ennek az elvnek az alapján kell ismét visszatérnünk az eredeti kérdésünkhöz, hogy mit jelent Vargha Gyula jelen írásban hivatkozott egykori, a miniszterelnökhöz címzett felirata. 
A fentebb adott válasz mellett (a gyakorlatban érvényesülő magyar nemzetépítés egyik indikátora) további felelet is adható. Jóllehet a térképek textuális megközelítése az alapvető kvantitatív jellegüknél fogva igen korlátozott, a „térkép mint szöveg” elv mégis hasznos betekintést nyújthat a térkép kódolt jelentésbeli rétegeibe. A nyomtatott képi információ is részben a szavaktól függ (Gombrich 2003), tehát a térkép ugyanúgy „rászorul” az ábrázolás hagyományait, a szerző őszinteségét, objektivitását, a térkép mögött kialakult konszenzust demisztifikáló, a szerkesztés kontextusát, célját, értelmét kritika alá vevő olvasatra, mint az irodalmi, filozófiai vagy tudományos szövegek.

Ám ebben az esetben az elkészült közigazgatási és egyben nemzetiségi térképpel szerencsés helyzetben vagyunk, mert ránk maradtak egyrészt a térképet megrendelo" szövegek, másrészt a teljes levélváltás, amely az elkészült térképre adandó intézkedési tervet tartalmazza. A jelen dokumentum tehát úgy is értelmezhető, mint a térképi tartalom szöveges leírása. Választ kapunk belőle arra az alapvető kérdésre, hogy tulajdonképpen hogyan kell értelmezni, helyesen dekódolni(!) a nemzetiségi térképet. De a tervezet mutatja a térképi kifejezés szűk határait is, hiszen hogyan is lehetne például a nemzeti karakterológiát megjeleníteni? (Esetleg utalhatna erre „valamiféle” közmegegyezéssel használt színkód.) A levél viszont éppen a textualitásával képes kereteket adni a nemzetiségi térképnek, azaz „megjeleníti” a térképen igen korlátozottan ábrázolható társadalmi/kulturális folyamatokat.

A dokumentum tartalmazza természetesen a térkép (a fentebb már kifejtett geofilozófiai tévedésekkel, tévutakkal együtt mégis valamiféle) „tudományos" olvasatát, tehát a csak statisztikai adatok alapján kirajzolódó téralakzatokból (zsák, tömb, etnikai határ) levont következtetéseket. Ám a felirat az elhallgatásaival, a sztereotípiáival, a sugallt értelmezési kereteivel, a (magyarnemzet-centrikus) látószögével mégis alapjában kérdőjelezi meg „a nemzetiségi kartográfia mint szigorú tudomány" tételt.

Amint fentebb már írtam, a nemzetiségi térkép inkább az adott kor nemzetpolitikai céljait alátámasztó vizuális jelrendszer, mintsem objektív helyzetértékelést nyújtó kartográfiai gyakorlat. Ebből következő természetes magyarázat tehát, hogy a századforduló politikus megrendelői felhívták a figyelmet az etnikai térképek kettős élére, hiszen azok „rossz, idegen kézben” akár éppen fordított célokra, azaz a magyarság ellen is felhasználhatók (részletesen 1. Keményfi 2004b). Ez a félelem az első világháború után természetesen eltünt, sőt a nemzetiségi térképeket most már a területvesztéssel veszélyeztetett magyar nemzet minél szélesebb körű szolgálatába állították. A kisebbségek térbeli helyzetét elemző bizalmas gyakorlatból a térkép propagandaeszközzé vált.

A kultúra/társadalom térbeli beágyazottságának, tagoltságának, a tér és a kultúra/társadalom kölcsönös viszonyának vizsgálata a magyar tudományosság mély gyökerü sajátossága. A német kutatások, elméletek (például a ratzeli determinizmus) talaján mozgó „nemzeti tudományokat” a táj és a kul- 
túra (néprajz, geográfia [1. a két tudomány viszonyának összegző bemutatását Keményfi 2004a]), sőt a táj/tér és a történelmi/politikai események (népiségtörténet [Csíki 2003, 2004; az irányzat kritikai bemutatását l. Erős 2000]) összefüggésének elemzése a huszadik század első felében lényegileg meghatározta. Ettől a szemléletmódtól csak igen nehezen tudtak és tudnak e tudományok a mai napig megszabadulni. Fokozottan igaz ez az elméleti megkötöttség a kulturális jelenségeket, folyamatokat, kölcsönhatásokat elemző néprajzra. A népi műveltség, életmód abszolút táji meghatározottságától megszabadult és a táji kötöttség helyett társadalomtörténeti szempontokat (például a polgárosodást) előtérbe helyező kutatások csak az utóbbi évtizedekben honosodnak meg a néprajztudományban. (A néprajzi térbeliség kérdésének elemzését l. Kósa 1990, 1998.) ${ }^{2}$

A nemzetiségi kartográfia (az objektív tér és nemzet/etnikum szoros összefüggésének ábrázolása) oka és egyben okozata is az előzőekben bemutatott nézőpontból történő vizsgálódásnak. Hiszen egyrészt a régiónk államhatárokon átnyúló, vérközösségi gyökereket elötérbe helyező álláspontja a nemzet, a nemzeti kisebbség fogalmát jórészt térhez (területváltozásokhoz) kötötten értelmezi, másrészt viszont a térképi megjelenítés erősíti magát a kultúrnemzeti alapelgondolást: az adott nemzetiség/etnikum stabilitását a mérhetőség és az így létrejövő adatbázis térképi megjelenítése is biztosítja. Éppen ezért szintén hallgatólagos közmegegyezés alakult ki arról, hogy például a Kárpát-medence etnikai sokszínűségét bemutató könyvekben nemzetiségi térképek is szerepeljenek. Azt mondhatjuk tehát, hogy a kultúrnemzeti elgondolásban a nemzetiség a nemzeti, etnikai kisebbség fogalmának nem csupán a viszonyrendszerére, társadalmi struktúrájára utal, hanem a közép- és kelet-európai nemzetállamok számára fontos térszerkezeti, geográfiai elemeket is magában foglalja. Egyrészt a nemzetiség, etnikai csoport nagysága a kultúrnemzeti meghatározásokból adódóan mérheto", térben leképezheto", másrészt ez a felfogás az etnikai határokat a történeti kontinuitás által legitimált térbeli rendként jeleníti meg, s ennek következményeként az államhatárok mozgását és burkoltan e határok megváltozásának lehetőségét is tartalmazza. Ebben a tudományos hálóban bontakozott ki a két világháború között teljes metodikai skálájával az a szerep, amelyet a nemzetiségi térképeknek már a századforduló is megelólegezett.

Természetesen nem lehet a mai kor mércéjével és értelmi-érzelmi világának szűrőjén át nézni a majd háromnegyed évszázada született tudományos elméleteket, fogalmakat. Az egykori elképzelések pontos értelmezéséhez átfogó eszmetörténeti kép felvázolására lenne szükség - például a korszak földrajzi vitáinak, kutatási témáinak, a geográfusok személyes motivációinak, szakmai kritikáinak értékelésén keresztül. A nemzetiségi térképek készítésének motivációi is jól magyarázhatók. Annyit azonban a jelen írás keretei között is ki kell emelni, hogy a nemzetiségi kartográfia alapvetően téves elméleti elgondoláson nyugszik. Művelői ki nem mondva úgy vélték, hogy az etnikai kartográfia megteremti az átjárhatóságot, a kapcsolatot az objektív tér és a mentális/szimbolikus társadalmi jelenségek között. 
A neokantiánus iskola a szellemtudományok tárgyát a 19. század végén határozottan elválasztotta a természettudományos vizsgálati úttól. A puha, változó társadalmi folyamatokat nem lehet objektív törvényszerüségekkel leírni (részletesen l. Ullmann 2007). Azaz nem mondható, hogy „valamilyen társadalmi folyamat azonos körülmények között azonos módon zajlik le." Nem lehet tehát a kétféle megközelitést és kutatási gyakorlatot összemosni. Úgy vélem, a nemzetiségi kartográfia a két eltérő szemléleti út között hallgatólagos átmenetként jelent meg a korszak geográfiájában. Átmenetként, mert ebben a térképészeti gyakorlatban olyan érvrendszer bontakozott ki fokozatosan, amely kvázi természettudományi fogalomrendszerrel és faktorokkal igyekezett az alapvetően változó társadalmi jelenségek közötti kapcsolatokat, összefüggéseket statikusan, állandóságot tükrözve magyarázni, sőt e folyamatok változatlanságát próbálta bizonyítani. A térképeket értelmező (és megrendelő) szóhasználatban olyan, a változatlanságra, determináltságra utaló kifejezések honosodtak meg, amelyek a mai napig elö-előfordulnak az etnikai földrajzban. Lásd például a bemutatott dokumentumban a magyarság „hullámtörő gát” szerepének taglalását (l. a tanulmány I. részének mellékletében bemutatott 4 . pont 6 . sorát), illetve lásd napjaink szóhasználatában a védelemre, szilárdságra, „megtörhetetlenségre” utaló, a térkép üzenetszerepét taglaló fentebbi részben már idézett kifejezéseket: „etnikai bástya”, „etnikai védelmi sáv”, „etnikai frontharcos”, „etnikai túszhelyzet”, „etnikai szellemi fegyver”.

Tehát, még ha el is fogadnánk a statisztikai nagyságra és a területi kiterjedésre utaló egzaktabb, a feliratban felvázolt osztályozási rendet, a lelki alkat és vélt viselkedési minták (például barátságos, illetve a magyarságot veszélyeztető) alapján készült nemzetiségi területi intézkedési tervjavaslat már a saját korában is igen ingoványos elméleti talajon állt. Ez a fogalomhasználat - minden megújulási törekvése ellenére - még ma is jelen van az etnikai földrajzosok körében. Napjainkban is jelennek meg olyan írások, amelyek a társadalomtudományoktól idegen természettudományos gyakorlatot követelnek meg az etnikai geográfiában is. Azt például, hogy az alapfogalmak egyértelmüek, kétséget kizáróak és megingathatatlanak legyenek (Farkas 2006). Ha ez a „kívánt” állapot bekövetkezne, akkor ismét ugyanoda térne vissza a tudományág, amin igyekeznie kellene mégiscsak túllépni. Hiszen az utóbbi évtizedek nemcsak a „teret mozdították meg”, hanem eleve olyan egyértelmünek vélt fogalmakat is megkérdőjeleztek, mint a nemzet. Jóllehet az elmúlt évtizedekben lokális terepen mozgó kutatók éppen azt szerették volna munkáikkal elérni, hogy az etnikai földrajz módszertana eltérjen, túllépjen a klasszikus geográfiai indukción, a szinte természettudományi törvényalkotáson, térképi statikusságon, és valamiképpen több legyen önmagánál, azaz szinte tiszta társadalomtudománnyá váljék, amely a puha etnikai folyamatokat a megújult/megújítandó módszertani eszközkészletével elemezni képes (1. a „problémás góc”, azaz a „meghaladandó” geográfiai indukció, törvényalkotás bemutatását: Tátrai 2006). 


\section{A nyelvhatárakció korában}

A kulturális folyamatokat elemző honi néprajz történetét végigtekintők sokszor vádolták meg a tudományt elméletietlenséggel és túlzott leíró jelleggel. A kritikai hangokat el kell fogadnunk, ám éppen a néprajzi térbeliség kérdésénél meg kell szorítanunk a bírálatok érvényességét. A nyugat-európai kulturális térelméletekben ugyanis a honi néprajz jó kapaszkodót, elméleti alapot talált a kultúra/etnikum és környezet összefüggésének bizonyítására, a saját, ilyen irányú elképzeléseinek elemzésére. Éppen ezért üdvözölte és igyekezett elméleti szinten is honosítani tudományunk a kulturális aerák tanát, illetve a zonalitás-elgondolásokat. Ám megint egy olyan elképzelés tünt fel a honi tudományos palettán, amely Nyugaton tulajdonképpen már a születésénél megoldatlan elméleti kérdések sorát vetette fel. A „terekben/tájakban etnikumok mint kultúrateremtő népek" elv igen hasznosnak bizonyult a magyar néprajz és földrajz számára a két világháború között. A tér és a kultúra szoros összefüggését igyekeztek bizonyítani, illetve a magyar kultúra „magterületének” tökéletes kultúraalkotó képességét kívánták geográfiai érvrendszerrel is alátámasztani. A nemzetiségi térkép ebből a nézőpontból nem más, mint a Kárpát-medence életképes, kultúraalkotó magyarságának térbeli katalógusa. Ebből a szemléletből az is következik, hogy ha vannak körülhatárolható területi etnikai eltérések, akkor azok tipizálhatók is. Csakhogy megint abba az elméleti problémába ütközünk, hogy tulajdonképpen a felirat alapjában nem a térképről leolvasható térbeli helyzetekről szól, (mondjuk, azokat osztályozva), hanem a kartográfia számára értelmezhetetlen társadalmi folyamatok alapján sorol be és javasol intézkedési terveket. A statisztikai hivatal elnöke mégis átlép e kérdésen, és feliratában kifejti „védelmi tipológiáját”. A társadalmi/kulturális jelenségek bonyolult hálója és az objektív tér között hidat ver egzaktnak vélt nemzetkarakterológiával, sztereotípiákkal, sőt elhallgatásokkal. Tehette ezt, mert pontosan értették mondandóját, hogy mi rejtőzködik az adott szín alatt a térképen. Hiszen a korszak földrajza teljes természetességgel használta geofaktorként, azaz tájtényezö-eröként a nemzeti sajátosságokat. Cholnoky a magyart a legszelídebbnek, míg a románt durvának, a szlávot összeférhetetlennek írja le, ami az adott táj képében is megjelenik. Ugyanígy tesz Prinz is, aki a nemzetiségi peremterületeket durva, a magyartól idegen granicsár népségnek tünteti fel (Cholnoky 1937, Prinz 1937).

A feliratban Vargha csak galíciai veszélyként emlegeti a mindenki által mégis pontosan értett zsidóságot. („A galicziai határon levő községek a bevándorlás elleni védekezés szempontjából is fokozottabb gondozásban részesítendők.")

A zsidóság fogalmi meghatározása, önmeghatározása, illetve a befogadó társadalom általi definiálása, és ennek megfelelően az empirikus statisztika vagy levéltári források alapján szervezett vizsgálata számos nehézségbe ütközik. Magyarország és Közép-Európa 19. és 20. századi történelme során a zsidóság meghatározható etnikumként (az állampolitikai szempontok: a nemzetállam 
koordinátái szerint), felekezetként (az emancipáció eredményeként, a polgári liberalizmus prioritásához igazodva) vagy az 1930-as évek tendenciáinak ismeretében fajként is. „Vajda Mihály írt egy esszéjében (1989) a közép-európai zsidó fogalmáról, az etnikumként, a felekezetként vagy a fajként (illetve az ön- és a társadalom különböző csoportjai által) történő definiálásának problémáiról, ami a vizsgált korszakok kényszereivel, politikai tendenciáival függött össze. Lényegében ennek alapján »kellett« megkülönböztetnünk egy ún. etnikai asszimilációt (ami mindenképpen megelőzi a hagyományos értelmü [...] felekezeti asszimilációt), aminek a meghatározása azonban gondot okozhat. Egyfelől kétségtelenül a dualizmus korszakában felgyorsuló, a polgárosodással összefüggő »nemzeti homogenizáció « összetett folyamatának keretében zajlott, aminek társadalmi, politikai, kulturális és tudati összetevői, illetve okai voltak (ahogyan a zsidóság fogalmának is megvannak a társadalmi, vallási, kulturális és mentalitástörténeti tényezői). Ugyanakkor ezen tényezők egyre erőteljesebb differenciálódása figyelhető meg a magyarországi zsidóság különböző csoportjainál, ami még nehezebbé teszi az etnikai asszimiláció folyamatának egységes rekonstruálását, és aminek ily módon az izraeliták anyanyelvváltása, valamint a nem magyar anyanyelvüek magyarul tudása csak egyetlen, kétségtelenül a legmegfoghatóbb mutatója lehet... (Kiemelés tőlem - K. R.)" (Csíki 1999).

A nyelvhatárakció időszakát - amint azt a felirat is érzékelteti - a zsidóságnak etnikumként való felfogása jellemezte. Habár ebben a megközelítésben (az etnikai karakter hangsúlyozása) mérési indikátorként szerepelt a zsidóság számának megállapítására, de önmagában semmiképpen sem állta meg a helyét az asszimilációs folyamatot jelző - csupán lokális, egy-egy kisebb területre igazolt - nyelvváltás adatainak „ráhúzása” a teljes hazai zsidóságra. Sőt! Az előzőekben leírtakat még azzal is ki kell egészítenem, hogy az említett korlátok miatt a népszámlálási adatsorok inkább csak a zsidóságban lezajlott kulturális folyamatok tendenciáiról adtak képet, ezek nem a teljesen lezajlott asszimiláció egzakt záróeredményei (l. az asszimiláció elméleti kérdésköréhez Gyáni 1993, 1997). Árnyalt elemzések mutatták ki, hogy a zsidóság társadalmi beilleszkedése többszólamú. A Gordon-féle asszimilációs modell jól leírja ezt a folyamatot. Sokszor csupán felületesebb nyelvi akkulturáció mutatható ki (a belső csoportszerkezet [pl. rokonsági rendszer: további endogámia], intézményhálózat érintetlenül hagyásával) és nem teljes beolvadás zajlott le (l. Kövér 1977, 1998). Ez a felfogás (a zsidóság mint etnikum, etnikai közösség) „kívülről” határoz meg, azaz az anyanyelvet tartja determináló jellegzetességnek, és úgy véli, a dualizmus évtizedeiben felgyorsuló (és felgyorsítandó) nemzeti homogenizáció sokrétủ folyamatában és az asszimiláció menetében a nyelvváltásnak (a zsidóság magyar anyanyelvűvé válásának) lehet meghatározó (és elégséges) szerepe (Hanák 1984). Az alapelvnek megfelelően a hazai népszámlálási statisztikák kimutatásaiban a zsidóság egyre nagyobb tömege jelent meg magyar anyanyelvűként (ez az önálló etnikum létjogosultságát - például Fényes Elek - tette feleslegessé) [Csíki 1999]). Az etnikumként törté- 
nő „,belső”, azaz önmeghatározás pedig a politikai cionizmus programját elfogadók között lesz jellemző a századfordulón.

Ugyanebben a korszakban a zsidóság meghatározásának másik módja - a 19. századi emancipáció eredményeként a közjogi felfogásban és a közhasználatban - a felekezeti jelleg kiemelése, illetve (1895-től bevett) valláskénti definiálása. Ez a definíció a zsidóság „tisztán” vallási tényezőivel számol csupán. Az önmeghatározás azonban ezúttal sem feltétlen felel meg „külső” szempontoknak. Az utóbbiak ugyanis nem számolnak a zsidó valláshoz kötődő erőteljes kulturális, életmódot meghatározó vagy identitási elemekkel, amelyek alapján a magyarországi zsidóság (az eltérő származás, a be- és megtelepedés sajátosságainak, de a polgárosodás lehetőségeinek különbözősége miatt is) egyre erőteljesebben differenciálódott, és ez elvezetett - Európában egyedülállóan - az ortodoxia által vallott „kétfelekezetiség” dominanciájához, illetve az 1869-es egyetemes gyülést követően a különböző irányzatok szervezeti elkülönüléséig. (Ezért, továbbá az elvallástalanodás következtében, a népszámlálások önbevallásra épülő felekezeti kimutatásai sem lehetnek megbízhatóak, és a valós tudati viszonyokat: a felekezeti hovatartozást, identitást sem tükrözhetik.)

A múlt század fordulóján azonban a zsidóság „etnikai helyzetét” élesen kettéválasztották. Mindezek, azaz a hazai zsidóság kedvező asszimilációja ellenére, a nyelvhatárakció időszakában a magyar politikai elitben komoly félelem élt, hogy nagyobb arányú, keletről érkező idegen bevándorlótömeg jelenik meg Magyarországon. Jóllehet ez az aggodalom nem volt teljesen alaptalan, hiszen Galíciában a századfordulón majd egymillió, Oroszországban pedig több mint ötmillió zsidó élt, ma már azonban az alapkutatásoknak köszönhetően tudjuk, hogy a századfordulón a galíciai zsidóság bevándorlása csupán mítosz volt (l. Pietsch 1988). A feliratban megfogalmazott, a galíciai bevándorlás feltartóztatását célul tűző ajánlás ezt az aggodalmat tükrözi. Sőt! Hogy milyen félelmetes képzetet jelentett abban a korban a galíciai zsidóság betelepülése, jól jelzi, hogy Vargha az alapjában a magyarság megerősítésére irányuló intézkedési tervben az e területen élő idegen ajkúak magyarságtudatát is igyekezett előmozdíttatni.

Ugyanilyen módon osztályozza a magyar államtérben a magyarsággal együtt élő nemzetiségeket is abból a szempontból, hogy az államegység fenntartásának nézetéből mely nemzetek lehetnek megbízhatóak, barátságosak. Természetesen ez az osztályozás nem haladja meg a kor etnikai sztereotípiáit, ám - amint arról már fentebb szó volt - ezekkel a leegyszerüsítésekkel „valamiféle" etnikai egység képezhető, amely homogenizáció egyrészt alapja lehet egy vélt nemzetpolitikai intézkedési tervnek. Az pedig, hogy a nemzetkarakterológia a 19. században a geográfia egzakt tárgyává vált, részben a földrajz leíró korszakának köszönhető. Az egyes földrészek, földfelszíndarabok bemutatása magában foglalta megfogható, leírható ismeretként az ott élő népek jellemének bemutatását is (részletesen 1 . Fodor 2006). E szemlélet beépült a magyar tájtanba, és a nemzetkarakterológia a tájat formáló egyik tényezővé 
vált (Teleki 2000a, 2000b). Részben viszont „a karakterológia kvantitatív tudomány" elv a fokozatosan kibontakozó statisztikatudománynak és e diszciplínán belül érvényesülő szemléletnek is köszönhető. A felirat osztályozási rendszere (barátságos, barátságtalan nemzetiségek) pontosan tükrözi a korszak azon szemléletét, amelyben a polgárosodás előrehaladta vagy elmaradása játszotta a fő nemzetiségi csoportképző erőt. Azok az etnikai közösségek, amelyek az elit megítélése szerint aktívan részt vesznek a Magyar Állam európai polgári felzárkóztatásában, alapvetően más karakterjegyekből „ismerszenek meg", mint azok, melyek e vélekedés szerint kevésbé igazodnak e cél megvalósításához (Vári 2006). ${ }^{3}$

Meg kell azonban jegyeznünk azt is, hogy a felirat és a korszak földrajza - az országban élő németséggel ellentétben - a peremterületeken élő nem magyar népességben már az állam egységes területét veszélyeztető erőt is látott, a nemzeti sztereotípiákban egyre élesebb jelzők jelentek meg, amelyek a szlovák és a román etnikumok önálló államlétre való alkalmatlanságát hangsúlyozták, kulturális életképtelenségét igyekeztek bemutatni (Bátky 1918).

Bár a nyelvhatárakció évtizedén már túlmutat az 1920-as béke, a trianoni döntés nyomán természetes módon felerősödött egyrészt a honi geográfiában a magyarság táji kötöttségének hangsúlyozása és a Kárpát-medencének mint a magyarság karakterét alapvetően meghatározó természeti formának az értelmezése, másrészt a Kárpát-medencei utódállamok népeinek „tudományosan" negatív megítélése (Hajdú 2006).

Ám a feliratból nem csupán a kor nemzetiségi területi „helyzetlétéről” kapunk képet, hanem arról a terminológiai hálóról is, amellyel a magyar államterület nemzetiségi térrajzát leírták.

A szórvány használatával párhuzamosan - a két világháború között - teljesedett ki a magyar tudományos fogalmi rendszerben a 19. század végének német szóhasználatából átvett népsziget, nyelvsziget kifejezés is (a terminus használhatóságáról a vitát l. Néprajzi Látóhatár, 2000, 1-2.). Amint a feliratban olvasható, az adott korszakban a nyelvsziget szóalak - a szórványhoz hasonlóan - még „nemzetsemleges” volt (l. pl. Balogh 2002). A meghonosodó terminus az adott népcsoport „szigetszerü” helyzetét, zártságát hangsúlyozta. Ebben az időszakban (a korábbi századfordulón), főként az alapkutatások hiánya miatt, nem csupán területi értelemben, hanem kulturális vetülettel együtt használták a kifejezést. Ez azt jelenti, ha valami a térben szigetszerü, akkor az kulturálisan is zárt rendszerként értelmezhető. Akkor ez a megközelítés nem hordozott feltétlenül negatív fennhangot. Gyakran használták lexikonok, levelek, országleírások szinonimaként, egymást fedő értelemben a sziget/nyelvsziget és szórvány alakot (l. ehhez a felirat egyes pontjait). Később viszont, a trianoni döntést követő évtizedekben a „nemzetsemleges” elöfordulások fel-felbukkanása mellett (például „oláh”, szász nyelvsziget) azt láthatjuk, hogy a terminus a saját (jelen esetben magyar) kisebbségi helyzetű „szigeteire” utaló szóalakká vált. Olyan kifejezéssé, amely a maga veszélyezte- 
tettségi olvasatával a határainkon kívüli, elsősorban más nemzetiségek által körülvett „szigetmagyarokban” elnyomott kisebbséget láttatott. Hirdette a magyarság kulturális zártságát, „érintetlenségét” (mi több, romlatlanságát). Ha használták is a kifejezést más nemzetiségekre, akkor is ugyanarra a viszonyrendszerre utalt a szó, ugyanazt a magyarságra vonatkozó „veszélyeztetési” tartalmat hordozta: a magyarság közé ékelődött eltérő (azaz „előretöro”) népelemek megjelölésére szolgált (a szórvány és a nyelvsziget kifejezés részletes bemutatását l. Keményfi 2005).

Ebben a szellemben igyekszik a felirat a kirajzolódó „etnikai geometriai idomokat" megszüntetni, a magyarság térbeli helyzetét a kiszögellésektől megszabadítani, tehát - az akció szellemének megfelelően - életképes etnikai tömböket képezni. Választható útként vázolja fel Vargha a miniszterelnöknek a betelepités gondolatát. A magyarság mesterségesen szervezett (még csak tervezett) migrációjában tehát nem elsősorban a lakatlan területek benépesítése (a demográfiai vákuum megszüntetése) a fó cél, hanem a felirat a telepítésben alkalmas etnopolitikai eszközt lát a nemzetiségi népnyomás (7. pont) ellensúlyozására. E szerencsésen ránk maradt hosszú felirat sürítetten adja vissza az egész akció esszenciáját:

1. A levél mutatja a Julián-Egyesület elképesztően nagy volumenü, az egész Kárpát-medencére megfogalmazott nemzetpolitikai koncepcióját, amely javaslatoknak csak egy, bár igen fontos részét képzi a magyarság területi bemutatása. A felirat a nemzetiségi statisztikát alakító demográfiai folyamatoknak (a népszaporulatnak, a kivándorlásnak, a betegségek hatásának) nyomon követését is javasolja, de fő feladatának a Julián-Egyesület fö célkitüzését, a peremmagyarság gazdasági, birtok- és kulturális viszonyainak javítását tekinti. Az egyesület kiemelt hangsúlyt helyezett a magyarság kulturális megerősítésére, iskoláztatására, amit Klebelsberg miniszterként később, a két világháború között tudott gyakorlati politikájába átültetni. A két világháború közötti időszakban teljes kultúrpolitikai programmá kidolgozott klebelsbergi, sokszor félremagyarázott kulturfölénygondolat csíráit már e nyelvhatárakció is tartalmazza, hiszen a magyar iskolaügy és a magyar nyelvű hitélet gondozása kitüntetett szerepet kap a tervezetben.

2. Vargha levele mutatja az egyesület politikai befolyását is, hiszen Klebelsberg a programot a korszak miniszterelnökeinek tudtával és hathatós támogatásával szervezte: „Az az elv, hogy az Egyesület csak az állammal a legszorosabb egyetértésben együttműködve érhet el sikereket, már az első szervezkedés alkalmával is kifejezésre jutott azáltal, hogy az Egyesület vezető tisztviselői jórészben állami funkcionáriusok voltak" (Petri 1937 13-14.).

Ez az alapvető helyzet azonban egyben meghatározza az akció keretében készült dokumentáció üzenetszerepét is. Nem csupán ebben a feliratban, ha- 
nem a levélváltás későbbi darabjaiban is nagy gondot fordítottak arra, hogy egyrészt maga az intézkedési terv, másrészt az elképzelésben megvalósuló etnikai térkép szigorúan zárt körben maradjon. Ez a mód nemcsak a kormányzati döntés-előkészítés természetes bizalmasságát jelzi, hanem egy sokkal mélyebb - nyugodtan írhatom - nemzetpolitikai meghasonlást is tükröz. Hiszen miközben 1868 óta a magyar politikai elit törvényi keretekben államnemzeti célokat hirdet, addig a háttérben a nemzetiségi területi „elsajátítás és kisajátítás" (Gyáni 2010) szorongása irányítja a gyakorlati politika tervezett lépéseit. Természetes, hogy ezek az aggodalmak, azaz hogy a Kárpát-medencében élő nemzetiségekben a magyar vezető elit az állam területi egységének a veszélyeztetését látja, nem kaphattak nyilvánosságot. Ám alapvetően nem az elkészítendő térképpel van önmagában „baj”, annak ellenére sem, hogy a majdani térképek kiosztását is igen bizalmasan akarják kezelni. Hiszen ebben az idöszakban a Magyar Állam nemzetiségi térszerkezete nyilt tananyag (Cholnoky 1906). A bizalmas kezelést alapvetően e nemzetiségi térszerkezet szöveges értékelése és az etnikai térkép alapján megfogalmazott, a de jure (!) egységes államnemzetben a magyarsággal egyenrangú alkotó népként élő nemzetiségek visszaszorítására irányuló intézkedési javaslatok határozzák meg: „Minthogy e tudakozódások teljesen magánjellegűek lennének s egészen esetlegesnek tüntettetnének fel, a valódi czélra való minden utalás nélkül: a mély tisztelettel alulirt hivatal úgy véli, hogy megbizatásának bizalmas jellege ellen ezen informáczió szerzésekkel semmit sem vétene; másfelől pedig ugy reméli, hogy ez úton feltűnés nélkül és könnyebben juthatna bizonyos tapasztalatokhoz, mintha azok más, hosszadalmasabb hivatalos úton, vagy egyéb módon szereztetnének be."

A fentiek tehát azt jelentik, hogy - a nyilvánosan publikált és használt nemzetiségi térképektől eltérően - a megrendelt etnikai térkép egy komplex nemzetpolitikai program részeként készült el. Ez a kontextus határozza meg alapvetően az etnikai térkép bizalmas jellegét. Tehát akkor járunk el a kartográfia-történetben helyesen, ha ennek az intézkedési tervnek a viszonyában értelmezzük az elkészült térképet. Ám mindezek mellett a legpontosabb választ arra, hogy mit jelent ez a kontextus, hogy mi az oka a bizalmas kezelésnek, egy 1907. június 10-én írt felirat tartalmazza. ${ }^{4}$ Ez részletesen feltárja az egész akció nemzetpolitikai célját. Úgy is fogalmazhatunk, hogy ez a dokumentum az értelmezési kulcs a nyelvhatár-intézkedési tervhez:

„- [...] Tüzetes tanulmányok ezek, az illető községek nemzetiségi és egyéb viszonyainak alapos megfigyelései, s minthogy természetszerủleg a nyelvhatáron levő $\mathrm{s}$ a nemzetiségekbe való beolvadással fenyegetett községekre fordíttatott itt is a legnagyobb gond [...]

- [...] Az így begyüjtött értékes adatok [...] valóban hasznot hozókká váljanak arra a czélra, a melyre gyűjtettek, a nyelvhatáron lévő s a nemzetiségektől fenyegetett magyarság védelmére.

- [...] A nyelvhatáron élő magyarság védelme, ellenálló képességének 
öregbitése s helyzetének javitása úgy gazdasági, mint kulturális és szocziális intézkedéseket is igényel [...]

- [...] Az igazgatás és kormányzat minden ágában fognak fölmerülni olyan teendők, a melyek a nyelvhatári magyarság védelmére szükségesek lesznek.

- [...] Ismételni bátorkodom, hogy a nyelvhatárokon élő magyarság védelmére irányuló akcziónak az egész kormányzat körére kiterjedőnek kell lennie, s ezért csakugyan legalkalmasabbnak látszik, ha a végrehajtás iránt való javaslattétel is egy, az egész kormányzat megbizottaiból alakított tanácsra bizatik."

Habár a hosszú éveken keresztül folyó előkészítő munka nem hozta meg a legfőbb eredményt, azt tehát, hogy törvényerőre emelkedjék a javasolt intézkedési terv (az ügyet az 1907. június 10-ei levélhez csatolt dokumentum szerint 1908. január 13-án „ad acta” tették), a tervezetben szereplő nemzetiségi térkép mégis elkészült. A térkép kivitelezése 1908 első felében jutott a végső szakaszához. A munka a Wekerle-kormány (1906. április 8. - 1910. január 17.) alatt fejeződött be. ${ }^{5}$

A nemzetiségi kartográfia a térképekkel szembeni követelményeit a múlt század első évtizedeiben már pontosan megfogalmazta: nyújtsanak világos képet az egymás mellett élő nemzetiségek földrajzi elhelyezkedéséről, tömegéről, települési helyzetéről:

1. adjanak képet arról, hogy hol élnek az adott nemzetiséghez tartozó lakosok;

2. adjanak a térképek információt azzal kapcsolatban, hogy mekkora az adott nemzetiséghez tartozók száma a területen (és az egymás közötti számarányról);

3. adjanak képet arról is, hogy a különböző nemzetiségekhez tartozók mennyire élnek egymás közelségében, és az etnikumok elhelyezkedése a térben mekkora keveredésre utal;

4. szemléltessék a népsürüséget (Jakabffy 1994).

A fentebb elemzett felirat pontosan tükrözi azon törekvéseket, hogy mind szerkesztésében (például újszerü kördiagram-módszer) mind összhatásában (például színalkalmazás') az elkészült közigazgatási és egyben anyanyelvi térkép plasztikus képet adjon a magyarság „térkitöltő” képességéről, a kisebbségek pillanatnyi geográfiai helyzetéről.

De ez igaz fordítva is. Egy „rossz, idegen kézbe” kerülő etnikai térkép a magyarság ellen is fordítható, hiszen az olvasata meg is fordítható. Nem véletlen, hogy minden iratot „bizalmas” jelzettel láttak el, illetve a térképek elosztásánál is fokozott elővigyázatosságra szólítottak fel. A statisztikai hivatalban készülő nemzetiségi térképek hasznáról, illetve az ország nemzetiségi/anyanyelvi térbeli helyzetét megjelenítő módszerekről a Miniszterelnöki Hivatal részletesen tájékoztatta az állami hivatalok vezetőit, hogy azokat a gyakorlati államigazgatási munkához - titkos, eligazító háttéranyagként - megrendeljék. Az akció keretében ugyanarra az adatbázisra épülve két térkép valósult meg: 
„A másik munkálat a fent idézett magas leirat azon kivánságához képest, hogy a helyzetnek s a fejlődésnek számokban való kimutatásán kívül annak grafikus ábrázolása is szükséges volna - az 1900. évi népszámlálás alkalmával talált nemzetiségi arányoknak községenkint való grafikus feltüntetése volt, olyképen, hogy minden egyes községet a térképen a lélekszámával arányos nagyságú kör ábrázol, a mely körnek a községbeli nemzetiségek arányszámához mért szeletei az illető nemzetiségnek megfelelő színnel festettek be. Az egész ország területe tizenkét nagy térképszelvényt foglal el; kettőt ezek közül kegyes megtekintés végett tisztelettel bátorkodom visszakérőleg idecsatolni" (az 1905. július 7-én kelt felirat részlete).

„E most készülő térképek egyik fajtája ugyanis azt leend hivatva szemlélhetővé tenni, hogy az ország külömböző nemzetiségei községenként miként vannak megoszolva, tehát a legkisebb közigazgatási alakulatokig lemenve, hogyan vannak a magyarság között elhelyezve. Ugy a magyarság, mint a külömböző nemzetiségek más és más szinekkel lesznek e térképen megjelölve és pedig minden községet egy-egy kör fog jelezni, mely természetesen a község lakóinak számához arányos lesz. Ha egy községben külömböző nemzetiségek laknak, ugy annak a községnek a köre annyi szeletre lesz felosztva, a hányféle nemzetiség a községben van s minden szelet az illető nemzetiség szinével lesz kifestve ugy, hogy a térképekre rajzolt mértékek alapján megállapitható lesz, hogy mennyi a község összlakóinak a száma, hányféle nemzetiség lakja az illető községet és hogy számarány szerint hogy oszlanak meg a nemzetiségek minden egyes községben. [...]

A statisztikai hivatalnál készülő térképek másik fajtája, ugyanezen rendszer szerint, azt van hivatva feltüntetni, hogy az ország lakói a magyarul tudás szempontjából - községenként - miként oszlanak meg.

A községeket e térképeken is a lakosság számarányához mért körök fogják jelezni, azonban e térképen csak kétféle szinezés lesz és pedig az egyik szin a község lakóinak magyarul beszélő, a másik szin pedig a magyarul nem tudó részét fogja graphikai uton feltüntetni."

Az 1868-as kisebbségi törvényből elvileg az következne, hogy az államtér nemzetiségektől függetlenül csak összefogja az ugyanazon jogi-politikai kerethez tartozó polgárokat. A területi határok csak a politikai kereteket jelölik ki, a térbeli etnikai határoknak tehát nincs jelentőségük. A magyar kisebbségi politika és törvényalkotás a 19. század közepén is ezen államnemzeti típus gondolati körében indult, ám a kölcsönös - vélt vagy valós - etnikai sérelmek oda vezették a Monarchia népeit, hogy azonos jogi-politikai keretben, azaz önálló, etnikai alapon szerveződött nemzetállami keretek nélkül már nem tudták elképzelni a mindennapjaikat. Amint a fent bemutatott dokumentumok is jelzik, az 1920-as esztendő területi döntése nem érte egészen váratlanul a magyar politikai elitet, hiszen már többévtizedes bizalmas „etnikai feltáró munka” folyt a háttérben. A dokumentumok másik olvasata viszont egy sokkal összetettebb cselekménysor egyik állomását jelzi - a nemzeti történetíráshoz, a népi kultúra képéhez hasonlóan -, a magyar nemzeti tér tudatos megszerkesztési folyamatának egyik száláról ad áttekintést. 


\section{Jegyzetek}

1 http://www.mtafki.hu/projekt_tf.htm

2 A néprajzi térbeliség kutatástörténetének összegzését a kartográfiai metódusra kihegyezve legújabban 1. Borsos Balázs akadémiai doktori értekezését (2008), amely még csupán kéziratban érhető el, de megjelenése várható. A magyar népi kultúra regionális struktúrája a Magyar Néprajzi Atlasz számítógépes feldolgozása fényében - kézirat.

3 Az imagológiai vizsgálatok egyik fó, hangsúlyozott része ma is a sztereotípia-elemzések területe. Hunyadi (szerk.) 2001, Hunyadi-Anh (szerk.) 2001, Horváth 2006. - Czirbusz (1913) véleménye szerint a délkeleti szlávság és a keleti románság morzsoló malomköve között a magyarság csak a németség rokonszenvére számíthat.

4 MOL. K 26. - 1909 - XXV. 181.

5 A nyelvhatárakció tervezetének ejtése valószínűleg Bosznia annexiójával lehet kapcsolatban. A feszült nemzetközi légkörben a magyar kormány nem akarta az ország területén belül élő nemzetiségekkel a viszonyt tovább rontani.

6 A térkép a magyarságot (természetesen) vörössel ábrázolja, a románságot - a minőségi kontraszthatásnak megfelelően - a telített vörös mellett tompa halvány barnával jeleníti meg.

7 A Magyar Állam közigazgatási térképe. Az 1900. évi anyanyelvi adatokkal kiegészítve. (1:360 000), Magyar Királyi Központi Statisztikai Hivatal, Budapest

\section{Irodalom}

Anderson, J. A. (2005): A kommunikációelmélet ismeretelméleti alapjai. Typotex, Budapest

Bátky Zs. (1918): Magyarország néprajza. In: Lóczy L. (szerk.): A Magyar Szent Korona Országainak Leírása. Magyar Földrajzi Társaság, Budapest

Biró A. Z. (1993): Centralizált hatalmi beszédmód. (Kiindulópontok a szocialista médiaszerkezetek pragmatikai szintjének emeléséhez). Antropológiai Mủhely, 2., 37-56.

Cholnoky J. (1937): Magyarország földrajza. Franklin-Társulat, Budapest, (A föld és élete; 6.)

Csíki T. (1999): Városi zsidóság Északkelet- és Kelet-Magyarországon. Osiris Kiadó, Budapest

Csíki T. (2003): Társadalomábrázolások és -értelmezések a magyar történeti irodalomban (1945ig). DE Néprajzi Tanszék, Debrecen

Csíki T. (2004): A néprajz- és történettudomány kapcsolatának problémái a dualizmus időszakában és a két világháború között. In: Veres L., Viga Gy. (szerk.): A Herman Ottó Múzeum Évkönyve. XLIII., 525-539.

Czirbusz G. (1913): A délmagyaroszági németek. Budapest

Erős V. (2000): A Szekfü - Mályusz vita. Csokonai Kiadó, Debrecen

Farkas Gy. (2006): Elméleti megfontolások az etnikai földrajz meghatározása kapcsán. In: Bakó B., Papp R., Szarka L. (szerk.): Mindennapi előitéletek. Balassa Kiadó, Budapest, 310-324.

Fodor F. (2006): A magyar földrajztudomány története. MTA Földrajztudományi Kutatóintézet, Budapest Gombár Cs. (1983): Újjászületik a geopolitika fogalma? Világosság, 8-9., 561-568.

Gombrich, E. H. (2003): A látható kép. In: Horányi Ö. (szerk.): Kommunikáció II. A kommunikáció világa. General Press Kiadó, Budapest, 92-107.

Gyáni G. (1993): Az asszimiláció fogalma a magyar társadalomtörténetben. Valóság, 4., 18-28.

Gyáni G. (1997): Polgárosodás mint zsidó identitás. BUKSZ, 3., 266-278.

Gyáni G. (2010): A tér nemzetiesítése: elsajátítás és kisajátítás. Helikon, 1-2., 239-257.

Gyurgyák J. (2001): A zsidókérdés Magyarországon. Osiris Kiadó, Budapest

Hajdú Z. (2006): A Kárpát-medence és a magyar államterület közötti kapcsolatok elemzése a magyar földrajztudományban 1863-1947 között. In: Győri R., Hajdú Z. (szerk.): Kárpát-medence: települések, tájak, térstruktúrák. Dialóg Campus, Pécs-Budapest, 390-417. 
Hanák P. (1984): A lezáratlan per. In: Hanák P. (szerk.): Zsidókérdés, asszimiláció, antiszemitizmus. Gondolat Kiadó, Budapest, 357-379.

Harley, John B. (1989): Deconstructing the map. Cartographica, 2., 1-20.

Hoppál M. (1992): Etnoszemiotika. Kossuth Lajos Tudományegyetem, Debrecen, (Néprajz egyetemi hallgatóknak; 14.$)$

Horányi Ö. (2006): Jel, jelentés, információ, kép. General Press Kiadó, Budapest

Horváth I. (2006): Kisebbségszociológia. Kolozsvári Egyetemi Kiadó, Presa Universitară Clujceană, Kolozsvár

Huntington, S. P. (1998): A civilizációk összecsapása és a világrend átalakulása. Európa Kiadó, Budapest

Hunyady Gy. (szerk.) (2001): Nemzetkarakterológiák. Osiris Kiadó, Budapest

Hunyadi Gy., Anh, Nguyen L. L. (szerk.) (2001): Sztereotípiakutatás: hagyományok és arányok. ELTE Eötvös Kiadó, Budapest

Huszti J. (1942): Gróf Klebelsberg Kunó életműve. MTA, Budapest

Jakabffy I. (1994): Magyarázat Közép-Európa nemzetiségi térképéhez 1942. Teleki László Alapítvány Könyvtár és Dokumentációs Szolgálat, Budapest

Keményfi R. (2004a): Földrajzi szemlélet a néprajztudományban. Kossuth Egyetemi Kiadó, Debrecen

Keményfi R. (2004b): „...A magyar nyelvhatárok, nyelvszigetek és szórványok védelme ügyében...." In: Kovács N., Osvát A., Szarka L. (szerk.): Tér és terep III. Akadémiai Kiadó, Budapest 119-131.

Keményfi R. (2005): A többrétegű „szórvány” kifejezés a kisebbségkutatásban. In: Illyés Z., Papp R. (szerk.): Tanulmányok a szórványról. Gondolat Kiadó, MTA Etnikai-Nemzeti Kisebbségkutató Intézet, Budapest, 78-90.

Klemperer, V. (1984): A Harmadik Birodalom nyelve. Tömegkommunikációs Kutatóközpont, Budapest Kocsis K. (1995): Közigazgatási változások Szlovákiában. Regio 6., 29-59.

Kósa L. (1990): A paraszti polgárosulás és a népi kultúra táji megoszlása Magyarországon (1880-1920). Kossuth Lajos Tudományegyetem Néprajzi Tanszék, Debrecen

Kósa L. (1998): Paraszti polgárosulás és a népi kultúra táji megoszlása Magyarországon. Planétás Kiadó, Budapest

Kövér Gy. (1977): Felekezet és nemzetiség az oroszországi értelmiség példáján a századfordulón. Történelmi Szemle, 2., 247-260.

Kövér Gy. (1998): Magyarország társadalomtörténete a reformkortól az első világháborúig. In: Gyáni G., Kövér Gy. (1998): Magyarország társadalomtörténete, 13-165.

Miklós P. (1980): Kép és kommunikáció. MUOSZ, Budapest

Neurath, O. (1991): Gesammelte bildpädagogische Schriften. Band 3. Verlag HölderPichler-Tempsky, Wien

Novitz, D. (2003): Képek és kommunikatív használatuk. In: Horányi Ö. (szerk.): A sokarcú kép, 363-400.

Peirce, C. S. (2004): A jelek felosztása. In: Kárpáti E. (szerk.): Szöveggyüjtemény a szemiotika tanulmányozásához. Aula, Budapest, 89-107.

Péter L. (1995): Klebersberg Kunó életrajza dátumokban. In: Zombori I. (szerk.): Gróf Klebersberg Kunó emlékezete. Keresztény Értelmiségiek Szövetsége, Szeged, 168-172.

Pietsch, W. (1988): A zsidók bevándorlása Galíciából és a magyarországi zsidóság. Valóság, 2., 46-58.

Rosengren, K. E. (2006): Kommunikáció. Typotex, Budapest

Schier, F. (2003): Az ikonikus referenciáról és predikációról. In: Horányi Ö. (szerk.): A sokarcú kép. Typotex, Budapest, 285-321.

Sipos A. M. (2006): Egy fejezet a Délvidék kulturális földrajzából. A Julián-Egyesület. In: Kókai S. (szerk.): A Délvidék történeti földrajza. Nyíregyházi Főiskola Földrajzi Tanszéke, Nyíregyháza, 203-237.

Tátrai P. (2006): Adalékok a települések belső etnikai térszerkezetének kutatásához. Földrajzi Értesító, 3-4., 273-286.

Teleki P. (1937): Egy néprajzi térképről. Földrajzi Közlemények, 60-70.

Teleki P. (2000a): Táj és faj. In: Ablonczy B. (szerk.), Teleki Pál: Válogatott politikai írások és beszédek. Osiris Kiadó, Budapest, 14-26.

Teleki P. (szerk. Ablonczy B.) (2000b): Válogatott politikai írások és beszédek. Osiris Kiadó, Budapest

Terestyéni T. (2006): Kommunikációelmélet. Typotex, Budapest 
Török Zs. (1987): A térképi modell dialektikája. Földrajzi Értesítő, 1-2., 143-152.

Ujvári P. (szerk.) (1929): Magyar zsidó lexikon. Pallas Irodalmi és Nyomdai Részvénytársaság, Budapest

Ullmann T. (2007): Neokantianizmus. In: Boros G. (főszerk.) Filozófia. Akadémiai, Budapest, 984-993.

Vajda M. (1989): Ki a zsidó Közép-Európában? Világosság, 8-9., 648-655.

Vári A. (2006): Etnikai sztereotípiák a Habsburg Birodalomban a 19. század elején. A sztereotípiaképzés funkciói és az állam tudománya, a statisztika fejlődése. In: Klement J., Miskolczy A., Vári A. (szerk.): Szomszédok világa. KSH Könyvtár és Levéltár, Budapest, 89-126. 